\title{
Competitive factors between local and foreign national small business retailers in South Africa: The case of Cape Town's Townships
}

\author{
Maphelo Malgas \\ Retail Business Management: Faculty of Business \& Management Sciences \\ Cape Peninsula University of Technology, Cape Town, South Africa \\ \& \\ College of Law \& Management Studies \\ University of KwaZulu-Natal, Durban, South Africa \\ Wellington .B. Zondi \\ College of Law \& Management Studies \\ University of KwaZulu-Natal, Durban, South Africa
}

\section{Keywords}

Small business retailers; township retailing; migrant small business; migrant entrepreneurship; small business challenges.

\begin{abstract}
This paper is based on the study that sought to identify the core competitive factors that differentiate foreign national small business retailers from local South African small business retailers in the way they operate their small retailing businesses. Primary research was conducted in two of Cape Town's (South Africa) townships, Delft and Eindhoven. The population of the study comprised two groups, namely, South African and foreign national small business retailers operating grocery retailer stores. The first group consisted of 55 South African small business retailers while the second group consisted of 75 migrant small business retailers. A random sample was targeted from each group and the quantitative research methodology was used in this study using a structured questionnaire with close-ended questions.

The results showed growth of foreign national retailers and decline in the number of the local retailers in the two townships. The study showed that migrant retailers have a competitive edge over local retailers. The study also revealed that most local traders have a lower level of education compared to their migrant trader counterparts. Furthermore, the study revealed that most of local small business retailers have never had a business finance mentor in their entire trading life. The study revealed that there is a need for a targeted funding model for potential and current local small business retailers. The study proposes a three-stage business intervention model to assist South African small business retailers to become more competitive in township retailing environments.
\end{abstract}

Corresponding author: Maphelo Malgas

Email addresses for the corresponding author: Malgasma@cput.ac.za; Maphelo.Malgas@gmail.com

The first submission received: $3^{\text {rd }}$ March 2021

Revised submission received: $13^{\text {th }}$ April 2021

Accepted: $19^{\text {th }}$ April 2021

\section{INTRODUCTION}

Since the dawn of democracy in 1994, South Africa has attracted foreign nationals from various countries in Africa as well as other parts of the globe. Some foreign nationals have found residence in the South African townships. The dawn of democracy also meant that people from the rural provinces of South Africa migrated to the big cities such as Johannesburg, Pretoria, Durban and Cape Town. This resulted in the development of informal settlements and informal stores (here in South Africa known as "spaza shops") for trading.

Informal settlements consist mainly of shacks (built of corrugated iron), and spaza shops are typically also shack-like structures. Spaza shops have sprung up in formal townships as well, as "convenience stores" saving people the long walk to general dealer stores in the town or city. 
Currently in South African townships, there is a perceived decline in the number of South African owners of spaza shops and a growing predominance of foreign national traders (Charman, Petersen \& Piper, 2012).

Charman, Peterson, and Piper (2012:66) noted that "in financial terms, the majority of Spaza's owned by foreign nationals equate to small size enterprises rather than micro-enterprises, as the scale of their operation and turnover is significantly greater than that of the average South African spaza". These authors argue that local small business retailers can be classified as survivalist entrepreneurs as they run their small businesses in their individual capacity without collaborating with each other. This assertion suggests that any business initiative aimed at entrepreneurial activity ought to be appreciated and encouraged, yet in the spaza shop sector this seems not to be the case.

In South Africa, the rate of unemployment is reported to be around $40 \%$ of the adult population; despite this, the number of people starting businesses due to having no other option for work (necessity entrepreneurship) is low, yet when foreign nationals start trading in township environments South Africans tend to have a problem with them operating in their townships (Singer, Amoros, \& Moska, 2014).

The aim of the study was to evaluate the trading capabilities of local South African traders and compare their competitive factors with those of migrant traders in the South African township retailing environments, then propose recommendations for South African traders to improve their trading capabilities in order to become more competitive in the township small business retailing sector.

The objectives of this study were as follows:

1. To identify the core competitive factors that differentiate foreign national small business retailers from South African small business retailers.

2. To propose recommendation for local traders to improve using the competitive factors of foreign national traders as guidelines to assist local retailers.

\section{Literature Review \\ Global challenges of small business retailing}

According to Erskine and Yong (2020), 80\% of small businesses established between 2005 and 2017 in the United States survived past their first anniversary and only about half of these businesses will see their fifth anniversary while one in three small businesses typically get to the 10 -year mark. The authors further noted that SMEs represent over $90 \%$ of the business population, $60-70 \%$ of the employment base, and $55 \%$ of Gross Domestic Product (GDP) in developed economies. Additionally, the authors stated that SME's can contribute as much as $45 \%$ of total employment and $33 \%$ of GDP in emerging economies.

Karadag (2015) noted that in Turkey, the significance of SMEs is relatively higher, and this is caused by their resilience to the shocks in turbulent Turkish macro economy. Furthermore, the author noted that Turkish SMEs were faced with serious challenges during and after the severe economic crises that hit the Turkish economy within the last three decades. The authors also stated that during that restructuring period, SMEs became one of the key elements of the macroeconomic improvements in Turkey, due to their significant role in the growth of overall GDP, new job creation and exports.

Aurick, Munalula, Mundia, Mwale and Vincent (2017) also stated that SMEs are key to the livelihood of people in the urban areas of Zambia. However, the authors further stated that SME owners in Zambia are faced with various challenges that constrain them to grow their businesses, to contribute towards the reduction of poverty as well as overall economic development. Qamruzzaman and Jianguo (2019) further stated that in Bangladesh the government should play a bigger by creating conducive conditions for financing innovation for SMEs in the financial system with integration of both formal and informal financial institutions. Moving a further step ahead, Nandonde and Kuada (2016) argued that the internationalisation process of firms is usually driven by both internal and external motives.

In developing countries, the lack of institutional capital is a major challenge for small businesses and most such enterprises are started with personal funds (Adisa, Abdulraheem and Mordi, 2014). The authors also noted that institutional finance requires collateral security, which small business owners do not have in developing countries. Erskine and Yong (2020) suggested that while there are a variety of reasons why SMEs ultimately fail, financial management skills and performance are two of the most 
often-cited explanations. Small and medium-sized practices (SMPs) can play a critical role in helping these SMEs to navigate an increasingly volatile operating environment (Erskine and Yong, 2020). In addition, the authors also noted some of the factors affecting small enterprise businesses such as:

- Factors driving SMEs' demand for business advice from SMPs, among others, include companyrelated factors (i.e., size, debt, age, growth, and available resources) and environment-related factors (i.e., economic conditions, including regulations, and competition).

- Market segmentation (e.g., start-ups, growth ambitions etc.) will impact the demand and type of advice provided.

- SMEs seeking business advice tend to be larger and younger and carry higher levels of debt or have greater aspirations to obtain new funding.

\section{Challenges and constraints facing small business retailers}

Badenhorst-Weiss and Cilliers (2014) observed that small business retailers face tough competition, more especially when it comes to pricing their products, because competitors can offer a number of substitutes, and this has a huge impact on the selling price of a product. The authors further argued that the proximity of competitors inflates this challenge because it means that the consumer has ease of access to alternatives, and small business owners must therefore strive to offer unique value to the consumer. Groenewald, Prinsloo and Pelser (2014) stated that entrepreneurs struggle to build a brand around their small businesses because they are usually not trained in brand management strategies.

According to Groenewald et al. (2014), it is important for the small business retailer to have a good understanding of innovative marketing strategies and not rely solely on outdated in-store visual merchandising as a marketing strategy, but also use social media marketing and branding tools to enhance their position. In addition to a lack of proper business and management skills/knowledge, small business face problems arising from poor record keeping and information management, an inability to separate personal funds from business funds, lack of adequate funding, and a lack of crucial infrastructural facilities (Adisa et al., 2014). The authors further stated that small business owners do not find it necessary to keep business transaction records such as invoices, bank statements (if they bank at all), purchase orders and stock-take records. However, the authors argued that in order to manage any business successfully, the business owner needs to keep up-to-date records of the business, including all finance records.

South Africa's rate of unemployment continues to rise, especially among the youth. It is evident from the data published by statistics South Africa that the South African government is not creating jobs for its economy. This has been further exacerbated by the Covid-19 global pandemic that started in China and had a very negative economic impact on South Africa economy. In order to revive the economy, the South African government has promised to support small businesses that have suffered greatly and in doing so the economy will be able to grow and create jobs.

Badenhorst-Weiss and Cilliers (2014) observed that small businesses close to malls have to compete by following survival strategies, such as selling cheaper products and adjusting their pricing strategy. The authors also stated that small businesses focussing on price differentiation as a strategy tend to survive and grow notwithstanding the increased competition. Furthermore, this appears to indicate that differentiation based on price (low prices and best value prices) may be a successful survival strategy in certain circumstances.

Makhitha (2017) noted that for independent retailers to remain competitive and survive, they need to select their suppliers carefully to be able to offer consumers what they want. Small business retailing has a large number of consumers but a low basket price, while the formal retail sector has a lower number of consumers with a higher basket price (Makhitha, 2017). Moreover, the author further argued that it is also important that small retailers meet customer specifications by providing appropriate products and services. Foreign national traders sell their goods at relatively low mark-ups for both cultural and commercial reasons (Gastrow and Amit, 2013). Moreover, the authors stated that because of their cheaper prices, foreign national traders turn over their stock quite quickly, and that is crucial for their survival in the informal retailing sector. The authors further suggested that the foreign national traders, Somali traders in particular, have a saying that "early loss is better than late profit"; in other words, slow trade turnover is worse than immediate losses. 
Charman and Piper (2012) argued that the South African government has over the years increased national spending on the development of informal settlements. The author also suggested that an increased spending by the government in the township should be of benefit to informal small business retailers as they need the infrastructure to develop and grow their businesses. Furthermore, South African small business retailers have very little choice but to make use of public transport to move their goods from the wholesalers to their own stores. In order to eliminate these transportation costs there is a need for them to collaborate with each other (Eicker and Cilliers, 2017). Moreover, the author suggested that the savings made from collaboration should be passed to the consumer in order for the South African retailer to gain some competitive edge over the foreign national trader. However, the author cautioned that the transportation system in South Africa is inadequate, and small business retailers need to take advantage of the times when traffic is moving freely, such as the late morning. They should use available public transport, such as taxis or trains (Eicker and Cilliers, 2017).

According to Ahmad and Alaskari (2014), small business needs to learn to market themselves better in order to improve their competitiveness. The authors also observed that if small business retailers could market themselves better, they would be able to increase their sales, but to do this they might have to rely on the word-of-mouth strategy or use social media as a marketing tool. Ahmad and Alaskari (2014) also claimed that the real challenge facing small business retailers is in part their culture of not assessing and projecting the sales growth, which leads to a lack of measurement and analysis of business progress.

\section{Foreign national trader competitiveness}

Chimucheka, Dodd and Chinyamurindi (2019) argued that the South African government should also show support for immigrant entrepreneurship in order to eliminate negative perceptions from other people in communities where immigrants operate businesses. The authors further argued that this can be done by developing policies that create an enabling environment for entrepreneurship by immigrants. In addition, the authors also suggested that financial institutions should also develop products for immigrant entrepreneurs in South Africa as they are a growing and promising market.

The success of foreign national small business retailers in South Africa is attributed to their social networking support for each other's enterprises and their entrepreneurial culture (Ntema and Marais, 2010). The authors also observed that that foreign national small business retailers are known for their work ethic, which is seen to be stronger than that of the South African small business retailer as they go to great lengths to create convenience for their customers. Additionally, the authors stated that the nonSouth African traders are significantly better educated than their South African counterparts and therefore have a sounder base from which to operate as businesspeople. Strydom (2015) suggested that South Africa is also ranked very low in terms of entrepreneurial culture, as entrepreneurship or business management does not form part of South Africa's early school curriculum. The author further observed that informal businesses that keep track of business activities such as financial records, do budgeting, prepare cash flow statements and have procurement documentation have a higher proclivity for survival.

It must be noted that competitors in any business are a very important element. The presence of foreign national trader usually conduces to business strategies like price cutting, advertising promotions, enhanced customer services - and not violent disruption (Chimucheka, 2013). Furthermore, the author noted that in an industry such as small business retailing where barriers to entry are very low, competition is usually fierce and can be increased by the bargaining power of customers and suppliers.

Wang (2016) argued that even though access to finance has been identified as the major obstacle for most small business entrepreneurs, infrastructure such as power connection and competition have also been identified as factors hindering the growth of small businesses. The author also added that there are also various external factors that hinder the growth of small businesses, such as the political climate of a country, and unfortunately there is nothing a small business can do to bypass these factors. Erskine and Yong (2020) also noted that access to finance can be a challenge for SMEs and this this can be due to their limited capital base and lack of a track record or due to the current economic climate of that region. However, the authors argued that with a credible forecast and projection coupled with good documentation and a compelling business plan, SMEs can have an easier access to finance from the credit provider. 
According to Charman, Petersen \& Piper (2012) South African Spaza shops are less competitive than foreign national run spazas. The authors further added that the majority of South African Spaza's are home based businesses, whereas foreign run Spaza's operate from a semi-detached room, or more commonly, from rented premises. Furthermore, the authors said that most South Africans operate their own shops or draw on family labour, whilst up to two-thirds of foreign shop keepers are employees. Some of these employees work under conditions akin to bonded labour. In contrast, the authors further suggested that the South African Spaza's owners are unable to match the collective purchasing power and labour advantages of the foreign businesses and have opted to either close their shops and/or focus on commodities in which they can sustain a competitive advantage, notably take-away food and liquor retailing.

\section{Competition and competitiveness among local small business retailers}

According to Eicker and Cilliers (2017), small business entrepreneurs always need to find a way of differentiating their businesses from their competitors. The authors added that when they differentiate themselves from competitors, they need to keep their customers in mind. Furthermore, the authors said that if the small business differentiates itself by improving customer care, it is likely to improve sales. Eicker and Cilliers (2017) concluded that customer service is the best way to differentiate a business from competitors; however, small businesses struggle with inventory management systems, and without the appropriate stock it is hard to serve customers. Furthermore, the authors also noted that small business retailers need extra storage facilities in order to back up any plan to serve customers better with available stock and products.

In order to be competitive, small business retailers need to be in close proximity to their customers and create the convenience that the customers need. Foreign national small business retailers collaborate with each other to use a centralised inventory management system, while local South African traders use a decentralised system in which each trader orders their own stock individually (Eicker and Cilliers, 2017). The authors also stated that collaboration or partnership would seem the way to go for South African traders to go in order to match this competitive advantage. Furthermore, the authors added that building and maintaining stock levels for a small business brings the cost of carrying stock, so greater storage capacity would make it easier for a small business to be responsive to customer needs as well reduce the risks of stock-out.

Competition and competitiveness in township retailing environments is about customers' buying power and their preferences, and therefore about understanding the consumer behaviour of the poor township dweller; it is also about the retailing skills of the small business retailer (Ntema and Marais, 2010). However, Eicker and Cilliers (2017) stated that local small business retailers usually focus on saving on the costs of managing inventory, but this detracts from their competitiveness due to being regularly out of stock of certain products.

Spremo and Mićić (2015) noted that small businesses are more capable of surviving a business crisis than large companies, partly because they have fewer employees. In the period 2008-2014, these authors further stated, having observed both developed and developing or transitional economies, they found that small enterprises have made a greater contribution to resolving the global problems of economic growth and employment. Furthermore, the authors noted that despite the obvious difficulties that small enterprises have faced during the global crisis in the period observed, there was a smaller decline in the number of small enterprises, value added and employment, than in large enterprises.

According to Elhennawi (2016), although the exact size of the informal economy is difficult to determine, it is clear that it represents a substantial proportion of African economies. The author also added that informal enterprises have several benefits from the social perspective, such as absorbing large numbers of unemployed people and providing products and services at lower prices. While the debate regarding the pros and cons of informal enterprises is ongoing, several benefits devolve from studying informal economy and its formalisation (Elhennawi, 2016).

Salimov (2018) argued that South African small business entrepreneurs need to focus on creating wholesale and manufacturing markets that are controlled by them in order to make sure that they are participating in the entire value chain of retailing. Moreover, the author added that in order to do that they need to partner with larger private enterprise through small enterprise development programmes 
and South African government development agencies. Salimov (2018) further claimed that government agencies can offer support in the provision of land and equipment, so that small business entrepreneurs can build the wholesales depots close to where they trade in the townships.

Regarding the Cape Town Metropolitan by-laws controlling informal small business retailers, some small business associations in the city view these by-laws as being biased against small business retailers and favourable to national retailers entering the township market (Battersby, Marshak, and Mngqibisa, 2017). The authors also added that these associations view the by-laws as unrealistic for spaza shops and unhelpful for the growth and development of small business retail entities in townships, where shopping malls with national chain retailers are now thriving.

\section{Research design and methodology}

In this study the research design used was an exploratory cross-sectional design. A quantitative research methodology was employed in the study and a survey research strategy was used employing the questionnaire as the research instrument

\section{Location of the study}

The study was conducted in Cape Town, South Africa in two specific townships, namely, Delft and Eindhoven. These two townships were chosen because they have a large population of both local and foreign trader retailers.

\section{Population of the Study}

The population of a research study is defined by Sekaran and Bougie (2016:236) as "the entire group of people, events, or things of interest that the researcher wishes to investigate". According to the information provided by the Livelihoods Organisation (2016), there were 89 small business retail stores owned by South Africans and 90 owned by foreign nationals in the two Cape Town townships of Delft and Eindhoven where the study was conducted, and these formed the population of this study.

\section{Sampling technique}

As indicated above the population of the study comprised two groups, namely, South African (local) and foreign national small business retailers operating grocery retailer stores, therefore each group had to be represented in the sample of the study. The first group consisted of 55 South African small business retailers while the second group consisted of 75 migrant small business retailers. The sample was selected using simple random sampling.

\section{Data collection instruments}

A structured questionnaire was used as the research instrument in this study and comprised of close-ended questions written in English.

\section{Data Analysis}

In this study the researcher analysed quantitative data using the Statistical Package for Social Sciences (SPSS). The data was arranged and presented in the form of frequency tables.

\section{Validity and Reliability}

In this study a sampling frame was carefully chosen, and a representative sample selected to make sure that the study was valid, reliable and generalisable. Strategies to secure validity and reliability for the quantitative research component included applied sampling processes, reports on the number of respondents and non-respondents, descriptive analysis of all data, and reports on statistical significance testing (Creswell, 2015).

\section{Ethical Considerations}

In this study all participants signed an informed consent form which was explained to them by the researcher. The recorded interviews did not include any personal details of the participants in order to ensure their anonymity. Data was collected at participant's place of business to ensure the participant's safety and convenience. All the data was coded, and the raw data is kept safe in line with the University of KwaZulu-Natal (UKZN) policy of data preservation. Furthermore, this study was cleared by UKZN's Research Ethics Committee, and an ethical clearance certificate was duly issued. 


\section{Findings and analysis \\ Response rate}

The response rate was $100 \%$ for the foreign national small business retailers and $75 \%$ for the South African small business retailers.

\subsection{Comparative factors analysis (Descriptive)}

\subsubsection{Gender}

Figure 4.1 (a) and Figure 4.1 (b) outline the gender disparity among local and foreign national traders in relation to the ownership of small business retail stores.

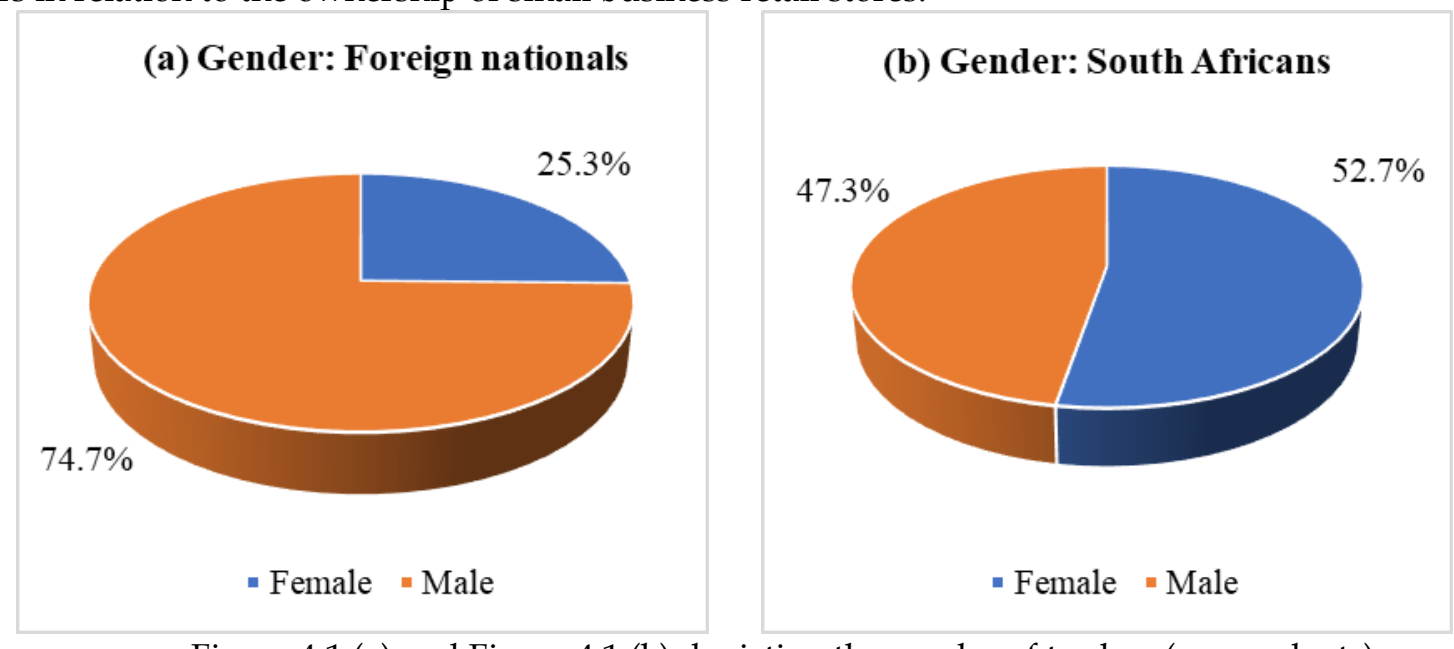

Figure 4.1 (a) and Figure 4.1 (b) depicting the gender of traders (respondents)

With regard to South African traders, Figure 4.1 (b) indicates that female traders are the dominant group, accounting for $52.7 \%$ of the respondents. Figure 4.1 (a) indicates that with foreign national traders the opposite is true, as male traders account for $74.7 \%$ of the total. Figure 4.1 (a) confirms a study conducted among African countries which showed that at least $37 \%$ of women (of working age) have start-up businesses, though this figure is 3\% lower than that of their male counterparts in that same economies (Kelley, Singer \& Herrington, 2016). In sum, the issue of gender in the informal retailing sector is very important because women experience discrimination in this sector: they are viewed as workers rather than business owners (Crush, Skinner \& Chikanda, 2015).

\subsubsection{Length of time operating business}

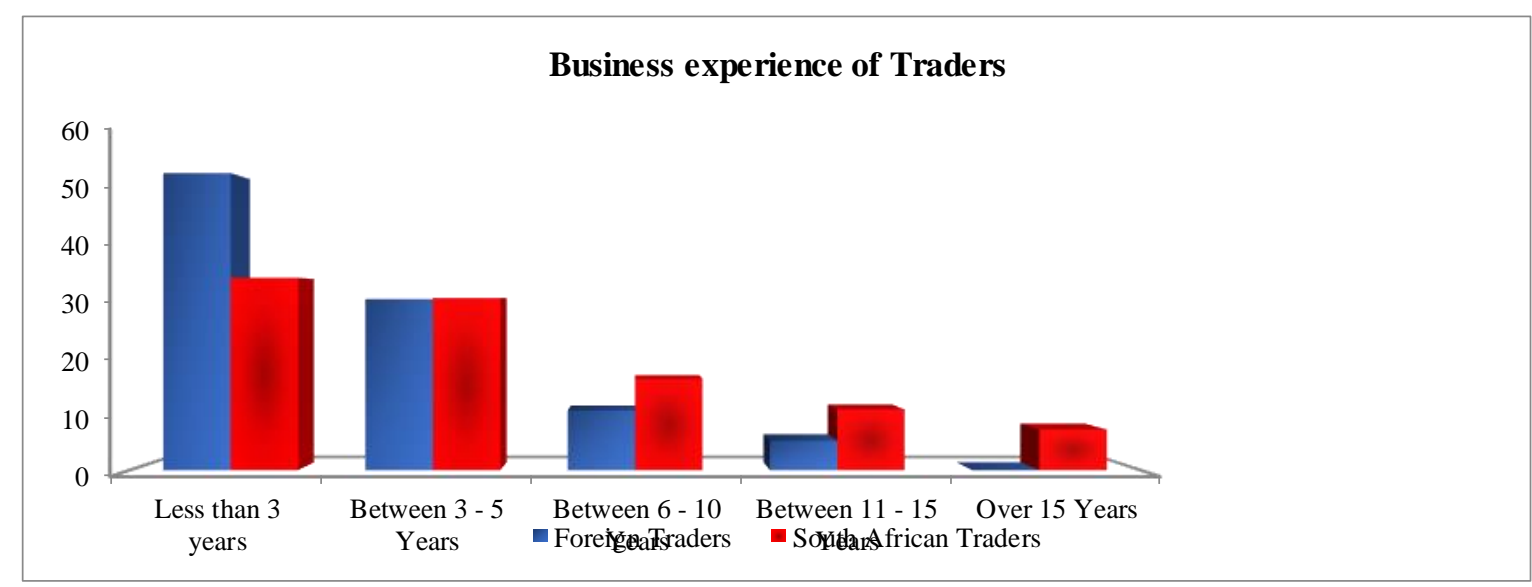

Figure 4.2 Number of years the businesses of traders had been in operation

Figure 4.2 above indicates that $34.5 \%$ of South African traders had less than 3 years of trading in the area, while $30.9 \%$ had between 3 and 5 years of trading in the area. This means that the $65.4 \%$ $(34.5 \%+30.9 \%)$ of South African traders had less than 6 years' experience of trading. With regard to 
foreign traders, as presented in Figure 4.2, 53.3\% had less than 3 years of trading in the area, and 30.7\% had between 3 and 5 years of trading in the area. The means that a large $84 \%(30.7 \%+53.3 \%)$ of foreign traders had less than 6 years' experience of trading. Entrepreneurs who have been in business for longer have the advantage of guaranteed and regular customers, while location remains the means-to-the end of street food enterprises (Otoo, Ibro, Fulton, \& Lowenberg-Deboer, 2012). Thus, vendors who have been in the business for a long period are able to secure a stable and fixed location to operate their businesses, unlike newer vendors, who lack permanent market locations and are obliged to change business locations regularly, affecting their accessibility to potential regular customers (Otto et al., 2012). Mrasi, Mason and Jere (2018: 32) also stated that in some areas retailers and consumers operating in the townships are continuously faced with the challenge of crime, as they are frequent targets of criminal activities

\subsubsection{Additional services}

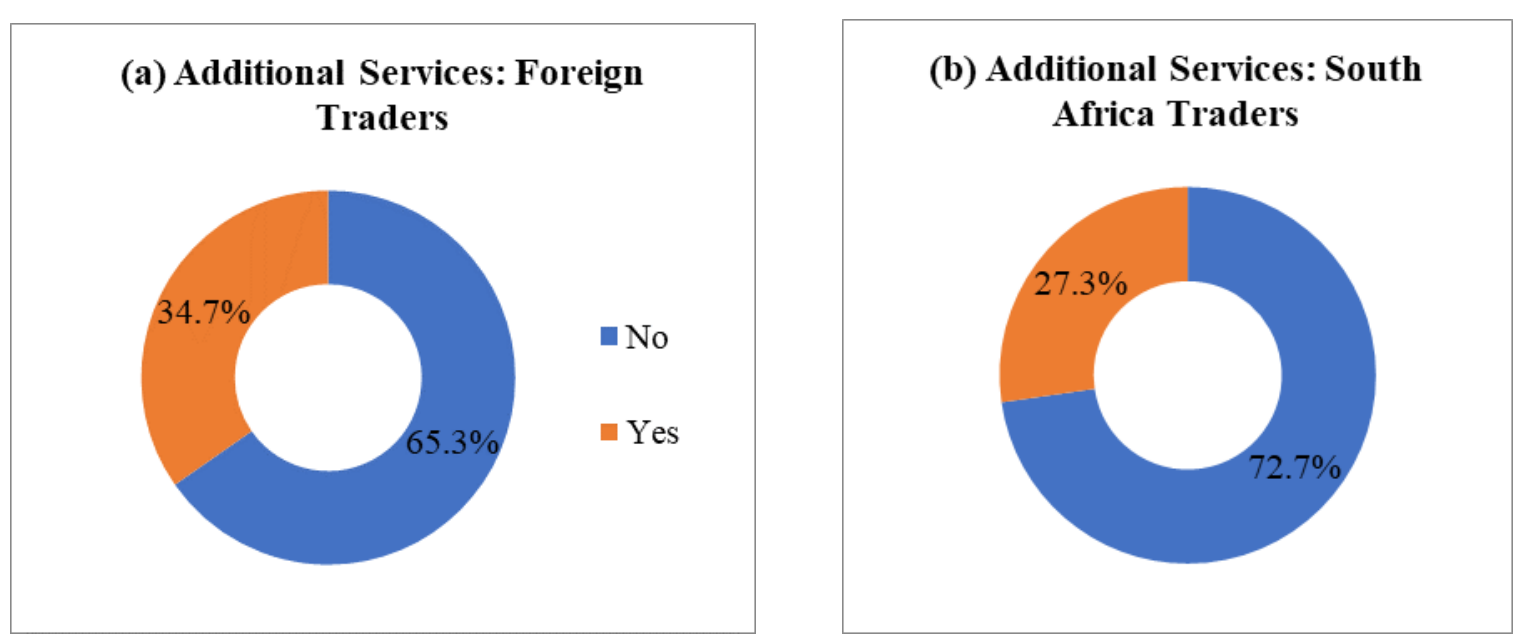

Figure 4.3 (a) and (b) depicts whether or not traders offer additional services

Figure 4.3 (b) above indicates that among South African traders, 72.7\%, a substantial majority, do not offer additional services (such as use of a telephone, airtime or photocopying) that are not part of their core business. In the case of foreign traders, as depicted in Figure 4.3 (a), 65.3\% do not offer additional services, while as many as $34.7 \%$ do. Gastrow and Amit (2013) comment that these service offerings make foreign national trader spaza shops owners popular among township customers. Furthermore, the author noted that foreign national small business retailers offer month-end specials to the consumers so that they can stretch the value of the money they spend on groceries. The author further noted that foreign national small business retailers offer additional services in their stores such as photocopying and selling other goods such as airtime to attract consumers. 


\subsection{Financial management and control analysis (descriptive)}

\subsubsection{Funding method}

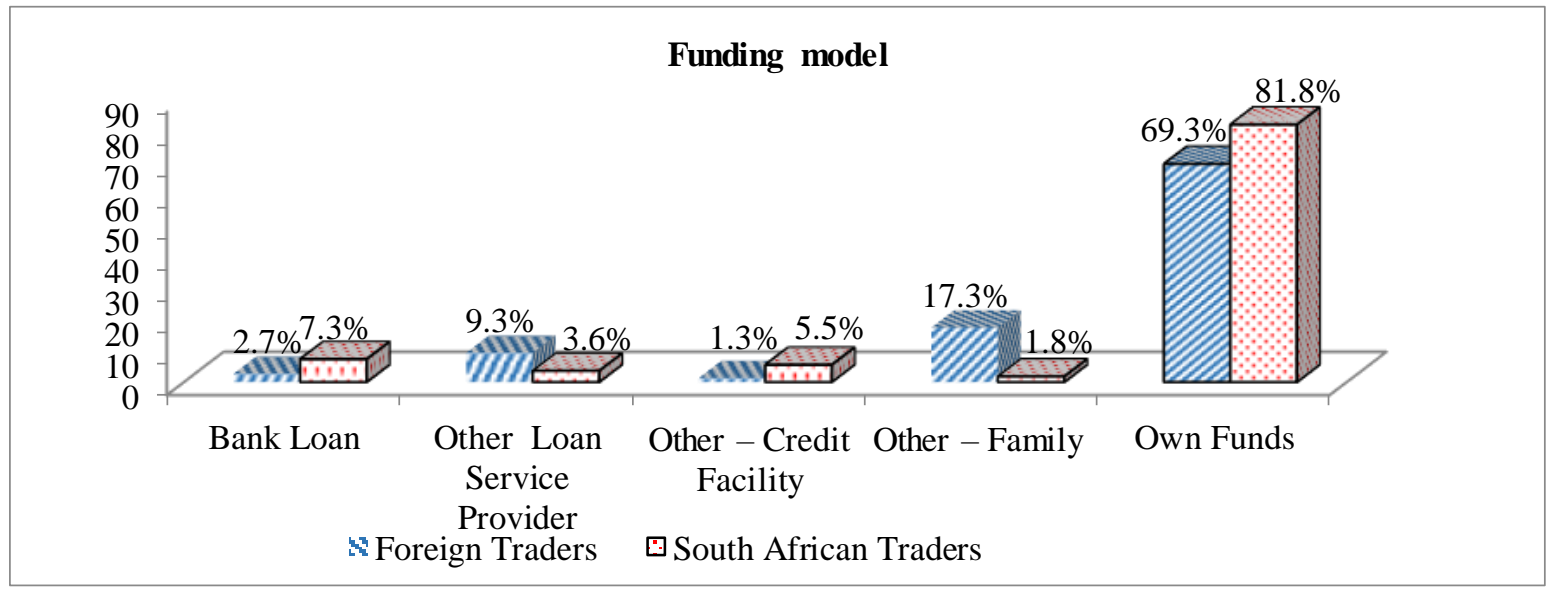

Figure 4.4 Funding method of foreign national and South African traders' businesses

Figure 4.4, above, indicates that among South African traders, a large majority of $81.8 \%$ preferred to use their own funds to start their retail business, or were forced by circumstances to do so. A smaller proportion (though still a clear majority) of foreign traders (see Figure 4.4) 69.3\% also used their own funds to start their small retail business. The figures indicate that it is a relatively small percentage of both local and foreign traders who use other forms of start-up capital, such as bank loans or family loans. Funding is often viewed as a stumbling block for small business start-ups, and potential new entrants, either local or foreign national, might be discouraged from starting a small business retail because of a dearth of funding options.

\subsubsection{Amount spent on rent}

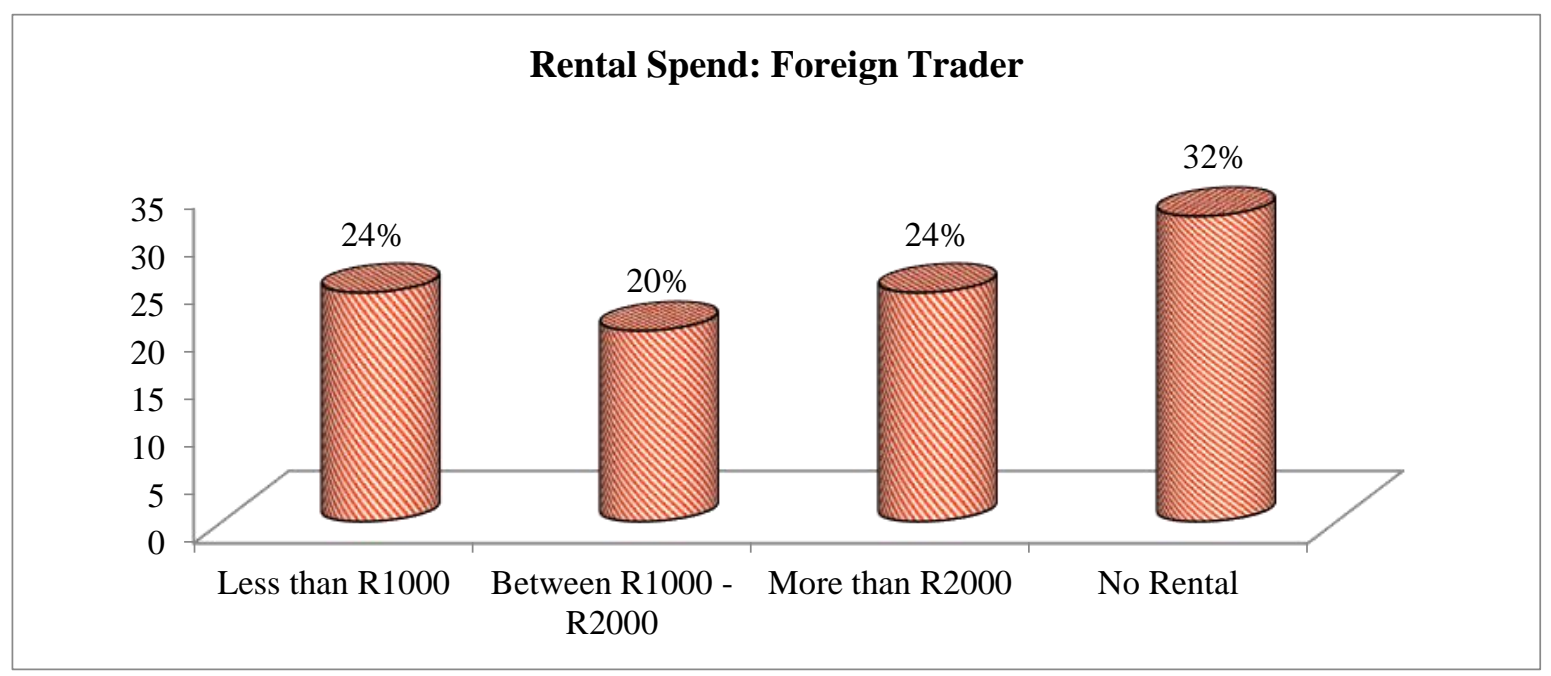

Figure 4.5 (a) depicting the amount spent on rent by foreign national traders

Figure 4.5 (b) below indicates that, among South African traders, 63.6\% pay no rent at all for their business premises, while $27.3 \%$ pay a relatively low rental of less than R1000 per month. In respect of foreign traders (Figure 4.5 [a]), only $32.0 \%$ pay no rental for their business premises, $34.7 \%$ pay a rental of between R1000 and R2000, while $24 \%$ pay a rental of less than R1000. This means that a majority of $58.7 \%$ pay a rental of less than R2000.

In order to save on dual rentals (renting space for the shop and renting a house to live in) foreign national traders usually just sleep at the store, meaning that their store doubles up as a home, which also helps to protect the store from criminal elements. However, the failed South African retailer usually 
accepts economic defeat and probably leases out their business to the foreign national small business retailer for a monthly rental income (Charman \& Piper, 2012).

\subsubsection{Rental Spend: South African Trader}

\section{Rental Spend: South Africa Trader}

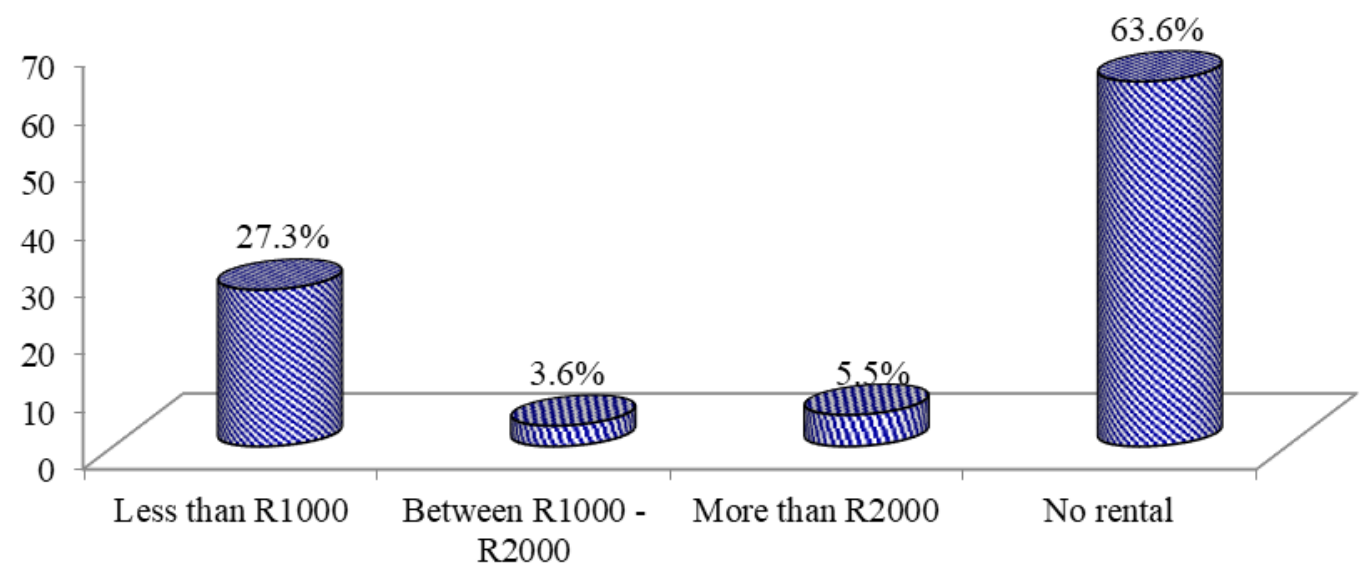

Figure 4.5 (b) depicting the amount spent on rent by South African traders

Figure 4.5 (b) indicates that a relatively small percentage $(9.1 \%)$ of South African traders that pay a rental of more than R1000, while this figure for foreign nationals is $44 \%$. Thus, the South African traders have some form of advantage when it comes to rental as the majority either own their stores or rent more cheaply.

4.2.4 Trader has a bank account or not

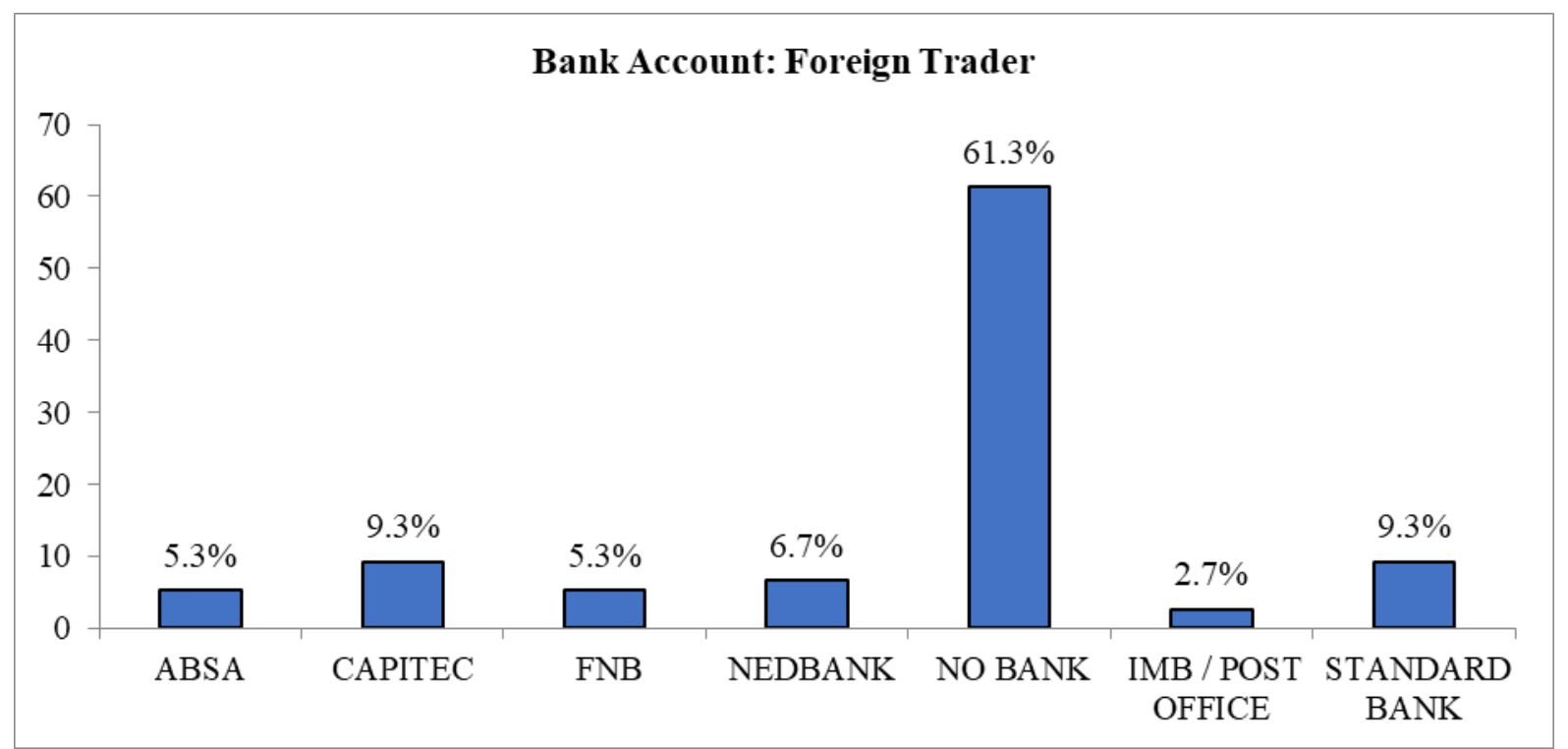

Figure 4.6 (a) depicting the bank where foreign national trader has an account

Figure 4.6 (b), below, indicates that $36.3 \%$ of South African traders do not use any form of banking, meaning that a majority $(63.7 \%)$ of South African traders use some form of banking for their business. Figure 4.6 (b) also revealed that $27.3 \%$ of South African traders prefer to use Capitec bank In South Africa Capitec is known as a bank that targets lower income earners. Among foreign national traders (Figure 4.6 [a] above), $61.3 \%$ do not use any form of banking for their businesses.

Bank Account: South African Trader 


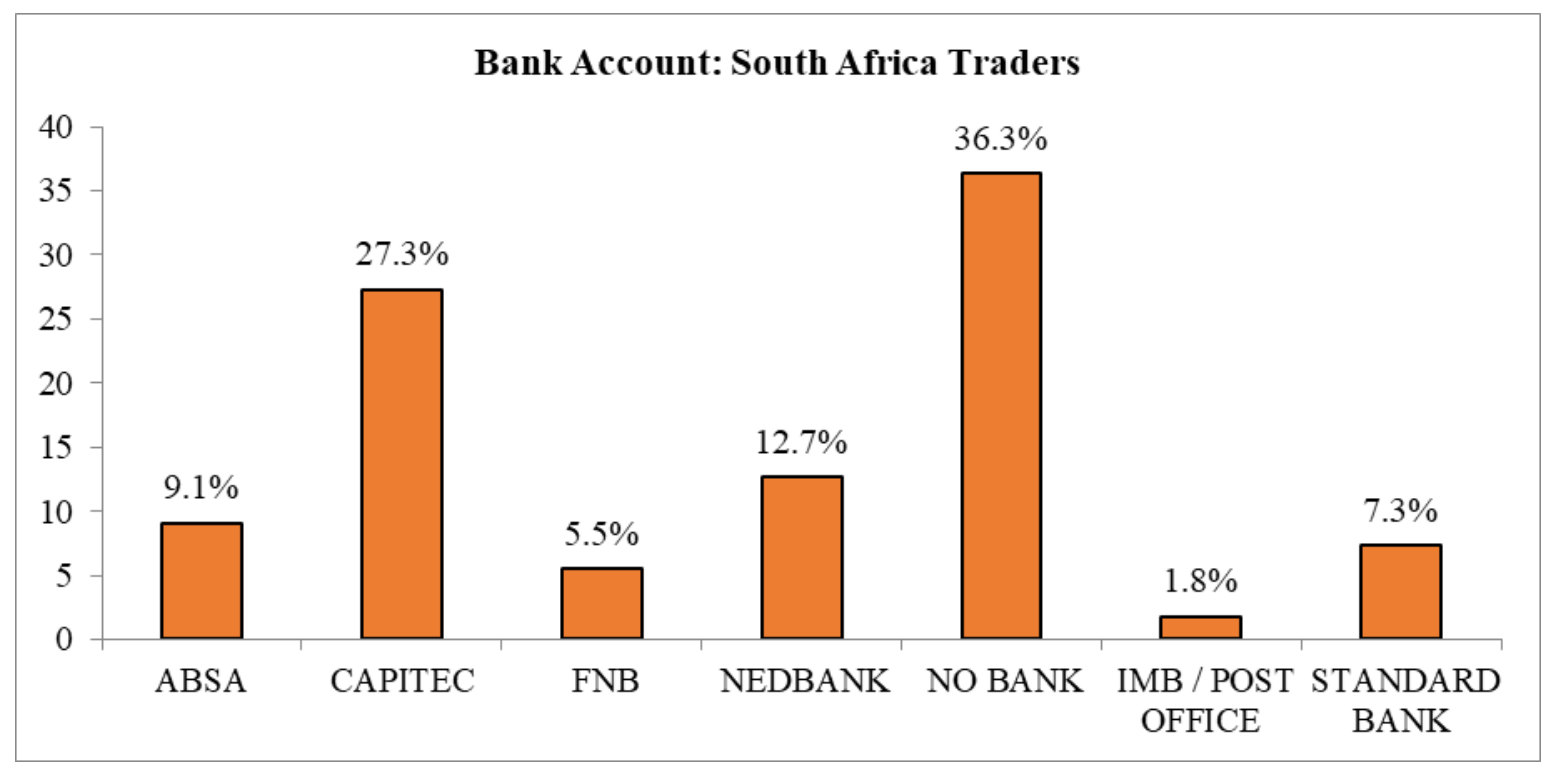

Figure 4.6 (b) depicting the bank where the South African trader has an account

South African traders who are not in the banking system miss the opportunity to be part of the formalised small business sector, which has certain benefits in the form of possible assistance from the government small business development agencies. Adisa et al. (2014) noted that small business owners do not find it necessary to keep business transaction records such as invoices, banking statements (if they bank at all), purchase orders and stock take records. Adisa et al. (2014) argued that in order to manage any business successfully, the business owner needs to keep up-to-date records, including records of all financial transactions. Furthermore, it must be noted that economic challenges for small business entrepreneurs in the informal sector in South Africa affect both local African small business retailers and migrant retailers. They alike lack access to finance, but for different reasons: for the migrant retailer, the reasons relate to being a foreigner (at times an asylum seeker), and for the South African retailer the reasons relate to the absence of audited financial and banking records because they do not even have banking records. Despite this shared handicap, migrant retailers seem to thrive compared to their South African counterparts (Crush et al., 2015).

\subsubsection{Monthly turnover}
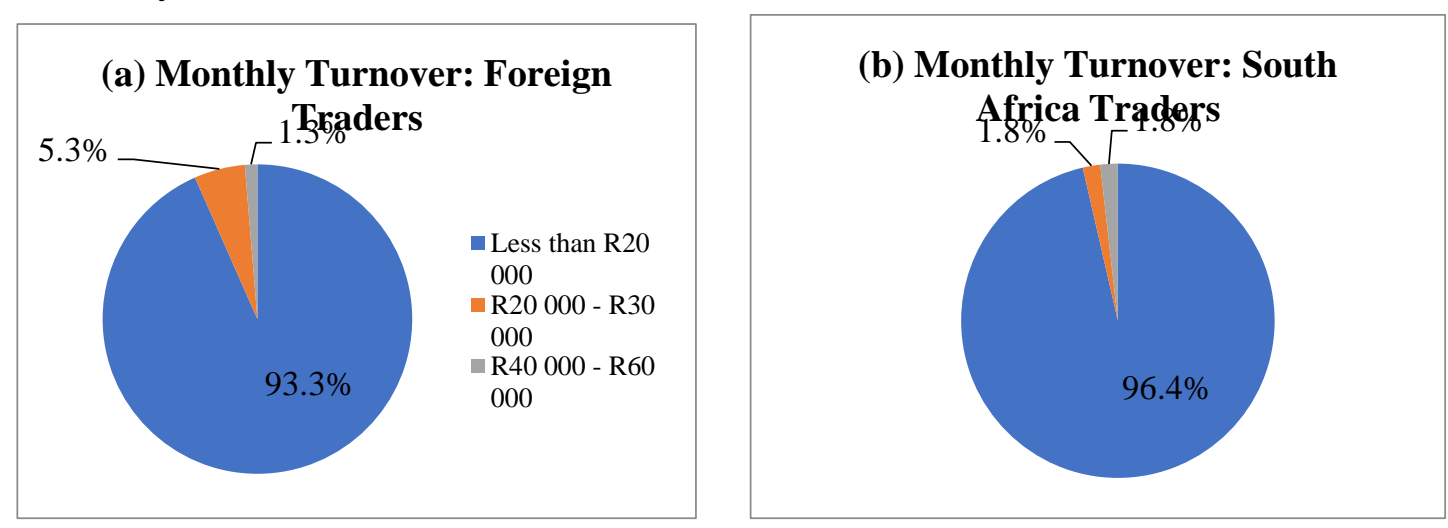

Figure 4.7 (a) and (b) depicting the monthly turnover of South African traders

Figure 4.7 (b), above, indicates that $96.4 \%$ of South African traders have a turnover of less than R20 000 per month. Among foreign traders (Figure 4.7 [a]), the figure is similar, with $93.3 \%$ also recording a turnover of less than R20 000 per month. Therefore, even if these small businesses were to be formalised, they would be exempted from paying any taxes as they are below the tax threshold in South Africa. 


\subsubsection{Financial Advisor}
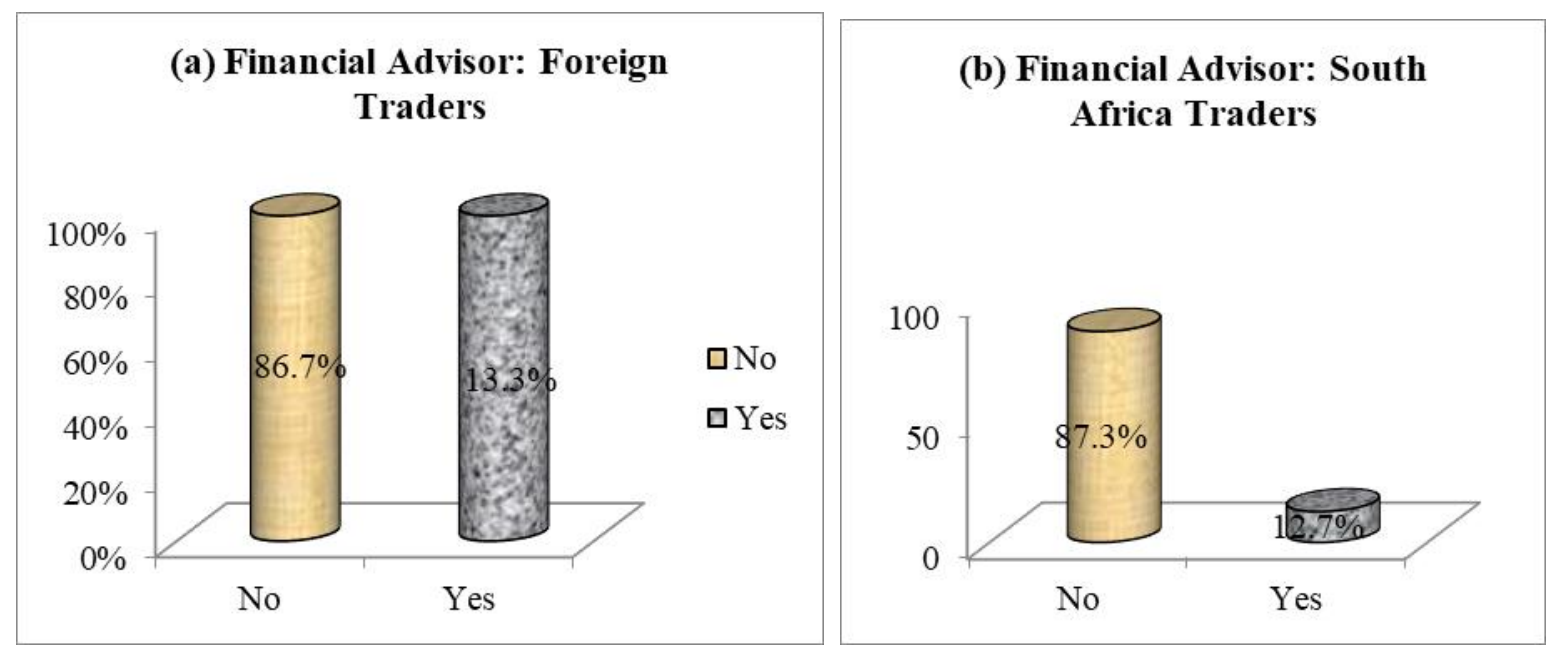

Figure 4.8 (a) and (b) depicting whether or not the South African trader has a financial advisor

Figure 4.8 (b) above indicates that among South African traders a significant majority of $87.3 \%$ have no-one to provide them with business advice or financial expertise. The figure is similar for foreign traders (Figure 4.8 [a]): $86.7 \%$ have no financial advisor. The figures indicate that few traders, whether local and foreign, have anyone to offer them business financial advice. Business finance requires special skills and formal business have highly qualified accountants to help manage the finances of the business. But small business cannot afford to pay for financial management skills and usually have to acquire these themselves.

\subsubsection{Financial management training}
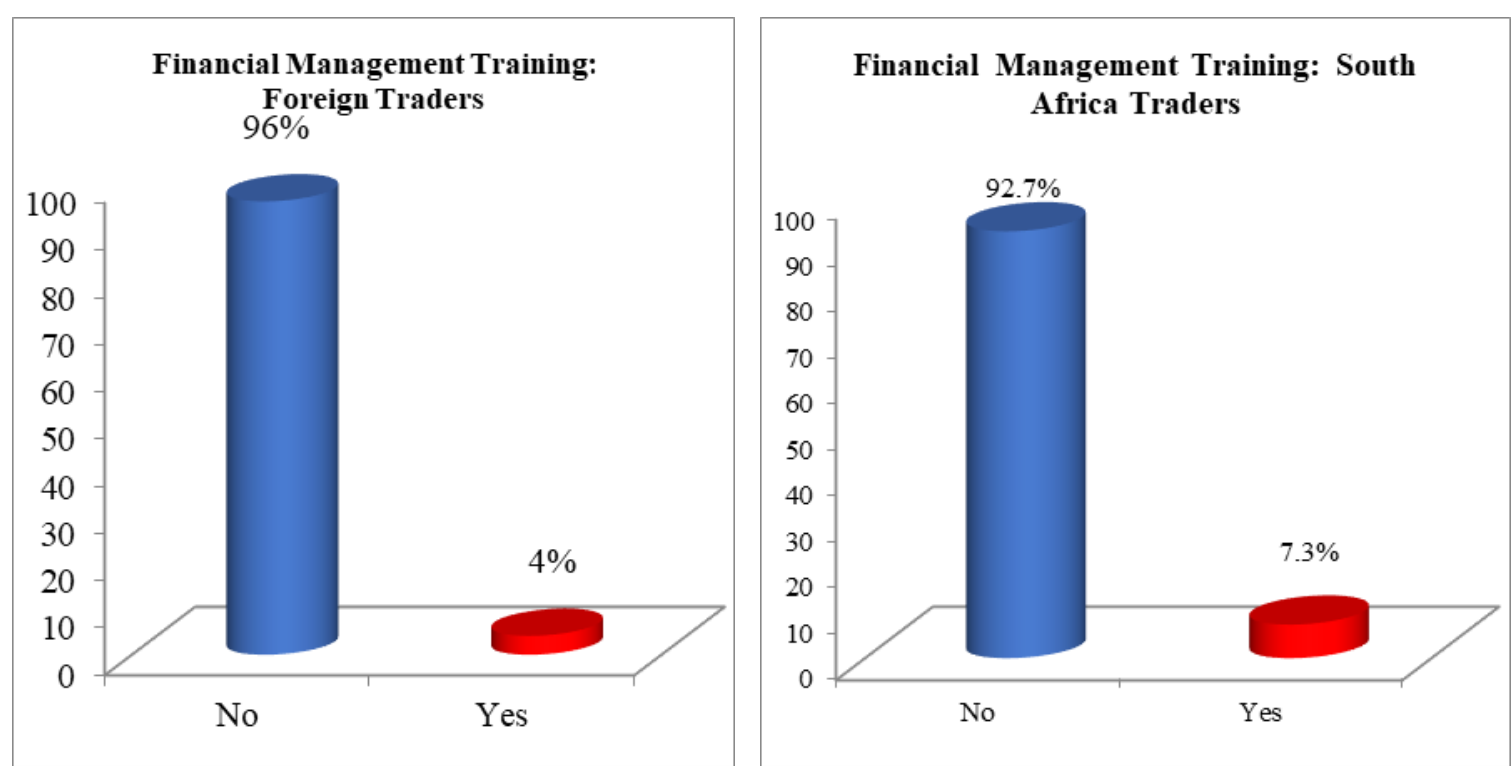

Figure 4.9 (a) and (b) depicting financial management training

Figure 4.9 (b) above indicates that a preponderance of $92.7 \%$ of South African traders have had no formal business financial training. An even higher percentage of foreign national traders $(96 \%)$ have had no formal business financial training. This is an area requiring urgent attention. This is in line with a research conducted in Turkey and it depicts that ineffective use of financial statements by SMEs and inadequate training and use of these has resulted in a high degree of failure in SMEs (Karadag, 2015). In

www.jbrmr.com A Journal of the Centre for Business \& Economic Research (CBER) 
Support, Erskine and Young (2020:1) stated that "While there are a variety of reasons why SMEs ultimately fail, financial management skills and performance are two of the most often-cited explanations. Small- and medium-sized practices (SMPs) can play a critical role in helping these SMEs to navigate an increasingly volatile operating environment".

Furthermore, Brijlal, Enow and Isaacs (2014) observed that financial management education and training of SMEs is vital for success of their businesses and called upon financial institutions to take a leading role in spearheading training and skills development. When business owners have no personal training in financial management, they typically make use of external financial management consultants, which unfortunately, small business retailers cannot afford, as cited by Brijlal et al. (2014). The fact that research results in financial management training for both South Africa and Foreign Traders indicated deficiency in financial management training, this calls for attention if traders are to survive in this volatile business environments (Thompson, Piteref, Gamble, and Thompson 2016).

\subsubsection{Credit facility}

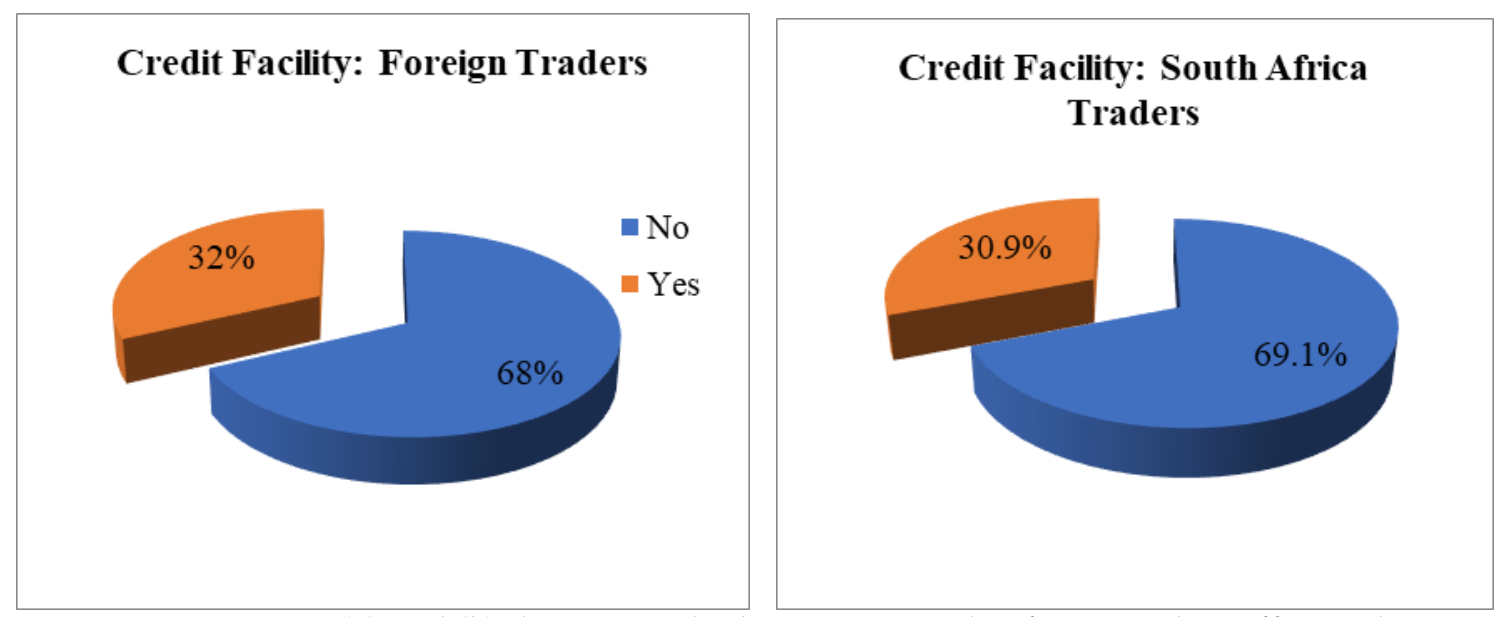

Figure 4.10 (a) and (b) depicting whether or not South African traders offer credit

Figure 4.10 (b) above indicates that $69.1 \%$ of South African traders do not sell on credit to their customers. As far as foreign traders are concerned, Figure 4.10 (b) indicates that a slightly lower proportion $(68 \%)$ do not provide credit to their customers. Credit can help traders to sell more to their customers, but it can also destroy the business if debts owing is not paid. If credit is provided by small businesses, it needs to be managed very carefully.

\subsubsection{Number of years trading in the area}
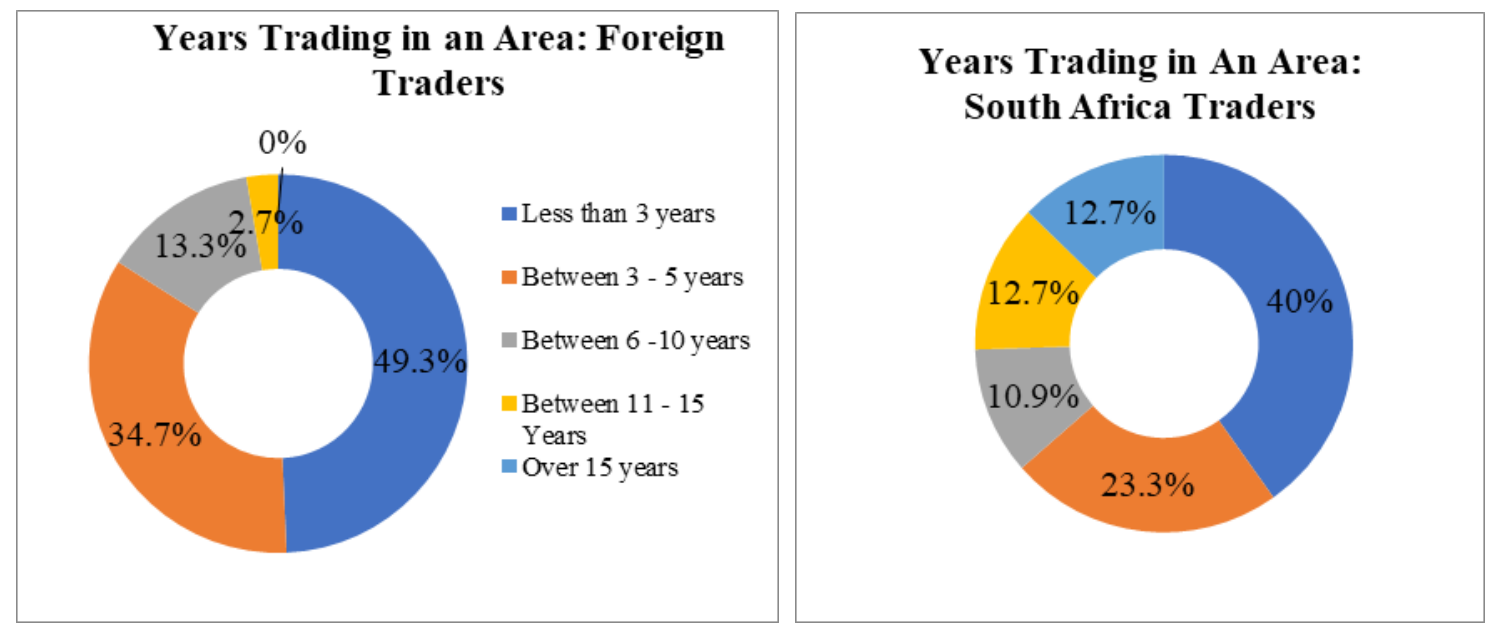

Figure 4.11 (a) and (b) depicting the number of years trading in the area 
Figure 4.11 (b) above indicates that among South African traders, $40 \%$ have been trading in the area for less than three years, with $23.3 \%$ reporting 3-5 years of trading in the area. This means that the majority $(63.3 \%)$ of South African traders have less 5 years' experience of trading in the area. For foreign national traders, Figure 4.11 (a) indicates that $49.3 \%$ of foreign national traders have less than 3 years' experience of trading in the area and $34.7 \%$ have between 3 and 5 years.

\section{Discussion of findings}

What is the core competitive factors that differentiate foreign national small business retailers from South African small business retailers in the way they run their small retailing businesses?

The first competitive advantage of foreign national traders is that they have more new start-up small business retail stores compared to local traders which means they are on the rise while local traders are on the decline. The threat of new entrants is one of the key factors identified by Porter (1988) as a factor to competitive advantage.

The second competitive advantage of foreign national traders is that they offer additional services in their business such as renting out a telephone, sell airtime and offering of photocopying services and these are not part of their core business. Gastrow and Amit (2013) commented that these service offerings make foreign national trader spaza shops owners popular among township customers.

The third competitive advantage for foreign national traders is that they are able to secure funding comparable to local traders. Funding is often viewed as a stumbling block for small business start-ups, and potential new entrants, either local or foreign national, might be discouraged from starting a small business retail because of a dearth of funding options.

The only area where local traders have an advantage is when it comes to rental because local traders do not pay any rent while local traders pay rent to those local traders who can no longer compete with foreign national traders. However, in order to save on dual rentals (renting space for the shop and renting a house to live in) foreign national traders usually just sleep at the store, meaning that their store doubles up as a home, which also helps to protect the store from criminal elements. However, Charman \& Piper, (2012) noted that the failed South African retailer usually accepts economic defeat and probably leases out their business to the foreign national small business retailer for a monthly rental income.

The study also revealed that the majority foreign national traders do use local South African banks probably because they send their profits to their countries of origin. However, there is also a significant amount of South African traders who are not in the banking system. This disadvantages local traders as they miss the opportunity to be part of the formalised small business sector which has certain benefits in the form of possible assistance from the government small business development agencies. Adisa et al. (2014) argued that in order to manage any business successfully, the business owner needs to keep up-todate records, including records of all financial transactions. Despite this shared handicap (not banking), migrant retailers seem to thrive compared to their South African counterparts (Crush et al., 2015). The study revealed that both foreign and local traders have a turnover less than the required ta threshold therefore even if they were banking and assessed for tax they would be exempted.

Another disadvantage of local traders is that they do not have any form of business advisory even though businesses require special skills and formal business have highly qualified accountants to help manage the finances of the business. In Support, Erskine and Young (2020:1) stated that "While there are a variety of reasons why SMEs ultimately fail, financial management skills and performance are two of the most often-cited explanations". When business owners have no personal training in financial management, they typically make use of external financial management consultants, which unfortunately, small business retailers cannot afford, as cited by Brijlal et al. (2014).

The fourth competitive advantage of foreign trader is that they offer credit to the consumers. Credit can help traders to sell more to their customers, but it can also destroy the business if debts owing is not paid. This also means that consumers probably view foreign national traders as people who understand their condition of being poor.

It must be noted that in South Africa during the Covid-19 (form March 2020) lockdown period the Department of Small Business Development announced an agreement with Nedbank to support spaza shops and general dealers on the back of the Credit Guarantee Scheme of Small Enterprise Finance Agency (SEFA). The scheme was only targeted to South African owned spaza shops as a relief for them to 
survive the lockdown period during which all businesses closed as mandated by the South African government. During the lockdown period small business from different sectors of the economy suffered greatly and had to close down. However, small businesses in small retailing sector were reported to facing challenges of accessing the support programme because of the following reasons:

Small business owners mentioned that it is difficult to take many hours away from a business to search for the information and apply for the support programme.

Some spaza shops are just frightened by a mere mention of mention of UIF and SARS as parts of the qualifying criteria for the support programme. One example is that of an extremely excited spaza shop owner in Delft who runs two successful spaza shops, one in Leiden and the other in Delft South, who got frightened away when a reporter explained the qualifying criteria and who never showed any further interest. Some weeks since the programme was announced most shop owners were still not familiar about the programme which therefore suggest an intense outreach is needed if the programme is to be successful

(https://www.iol.co.za/business-report/economy/bbc-starts-its-facilitation-activities-in-smallbusiness-development-programme-49561000).

Battersby (2020:1) argued that the South African government's lockdown (as a result of Covid-19) regulations have demonstrated considerable bias towards the large-scale formal actors and pushed towards formalization of the informal sector through the conditions about who is able to operate, and the conditions placed on relief measures.

\section{Recommendations}

The main purpose of the paper was to identify the core competitive factors that differentiate foreign national small business retailers from South African small business retailers and use these to fashion some guidelines to assist local retailers.

\section{Recommended Intervention for local Traders}

It is recommended that local traders should be trained in small business retailing through the Wholesale \& Retail Sector Education Training Agency (W\&R SETA). W\&R SETA is the custodian of the training needs of small business retailers as it in their mandate to train business retailers. The training must be specifically targeted at small business retailers and cover various aspects of managing a small retail business. The training programme will afford traders an opportunity to undergo a period of incubation. On completion of the incubation programme, the trader should also undergo mentorship, in terms of which the trader will benefit by getting new business knowledge and capacity from a mentor, and perhaps benefit from being introduced to new business suppliers and networks known to the mentor. Following on the training model the study proposes the formation of formal business networks for local small business retailers, to be initiated by the South African government's Department of Small Business Development. The network should be responsible for information sharing and exploration of further business opportunities among the small business retail community.

\section{Conclusion}

The above discussion has indicated that the problems faced by South African traders are not necessarily different from those faced by foreign national traders. However, foreign national traders seem to deal with the challenges differently compared to local traders in relation to factors such as lack of funding, lack of business networks and professional cooperation. Foreign national traders use their networks (social capital) to overcome the challenges while local traders are fragmented and operating in silos. South African traders are mainly faced with the challenge relating to funding and a lack of collaboration among themselves. In order to mitigate against this challenge local traders, need to work together through various government agencies as recommended above.

\section{Acknowledgements}

The author would like to thank the University of KwaZulu-Natal Graduate School of Business E Leadership for support in conducting this research.

\section{Competing interests}

The author declare that they have no financial or personal relationships that may have inappropriately influenced them in writing this article. 


\section{References}

Adisa, T.A., Abdulraheem, I. \& Mordi, C. 2014. The characteristics and challenges of small businesses in Africa: an exploratory study of Nigerian business owners. Economic Insights, III (LXVI)(4):1-14.

Aurick, M., Munalula, M., Mundia, L., Mwale, N.S. and Vincent, K., 2017. Urban informality and Small-Scale Enterprise (SME) development in Zambia: An exploration of theory and practice. Journal of Behavioural Economics, Finance, Entrepreneurship, Accounting and Transport, 5(1), pp.19-29.

Ahmad, M.M. \& Alaskari, O. 2014. Development of assessment methodology for improving performance in SME's. International Journal of Productivity and Performance Management, 63(4):477-498.

Badenhorst-Weiss, J.A. \& Cilliers, J.O. 2014. The value of a price differentiation strategy for small retail and wholesale businesses amongst price-sensitive consumers. Journal of Contemporary Management, 11:534-555.

Battersby, J., Marshak, M. \& Mngqibisa, N. 2017. Mapping in the invisible: the informal food economy of Cape Town, South Africa. African Food Security Urban Network (AFSUN), 24:1-47.

Battersby, J. 2020. South Africa's lockdown regulations and the reinforcement of anti-informality bias. Agriculture and Human Values, p.1.

Brijlal, P., Enow, S. and Isaacs, E.B., 2014. The use of financial management practices by small, medium and micro enterprises: a perspective from South Africa. Industry and Higher Education, 28(5), pp.341-350

Charman, A., Petersen, L. \& Piper, L. 2012. From local survivalism to foreign entrepreneurship: the transformation of the spaza sector in Delft, Cape Town. Transformation: Critical Perspectives on Southern Africa, 78:47-73.

Charman, A. \& Piper, L. 2012. Xenophobia, criminality and violent entrepreneurship: violence against Somali shopkeepers in Delft South, Cape Town, South Africa. South African Review of Sociology, 43:81-105.

Chimucheka, T., Chinyamurindi, W.T. and Dodd, N., 2019. The Effect of the Use of Social Networks on the Performance of Immigrant Entrepreneurs Operating Smmes in the Eastern Cape Province, South Africa. Academy of Entrepreneurship Journal, 25(4), pp.1-15.

Chimucheka, T. 2013. Overview and performance of the SMMEs sector in South Africa, Mediterranean Journal of Social Sciences, 4(14):783-795.

Creswell, J.W. 2015. A concise introduction to mixed methods research. Thousand Oaks, CA: Sage.

Crush, J., Skinner, C. \& Chikanda, A. 2015. Informal migrant entrepreneurship and inclusive growth in South Africa, Zimbabwe and Mozambique. Migration Policy Series, 68:1-72.

Eicker, T. \& Cilliers, J.O. 2017. Equipping small business retailers to manage logistical supply chain drivers: a theoretical guideline. Journal of Transport and Supply Chain Management, 11(0):12.

Erskine, R., and Yong, J., 2020. Performance and Financial Management: Key Factors for

Elhennawi, K. 2016. Factors affecting business informality among Egyptian opportunity entrepreneurs: an exploratory study. Journal of Developmental Entrepreneurship, 21(4):490-510.

Gastrow, V. \& Amit, V. 2013. Somalinomics: a case study on the economics of Somali informal trade in the Western Cape. ACMS Research Report, 1-37.

Groenewald, A.C., Prinsloo, J.J. \& Pelser, T.G. 2014. Strategic marketing insights for small business meat retailers. International Business and Economics Research Journal, 13(3):525-538.

Kelley, D., Singer, S., \& Herrington, M. 2016. Global monitor report (2015/16) Global Report.

Makhitha, K.M. 2017. Independent retailers in South Africa: how do they select their suppliers for survival? Journal of Contemporary Management, 14(14):416-440.

Mrasi, A.P., Mason, R.B. and Jere, A., 2018. Critical skills and knowledge to succeed in the township liquor retail industry. Journal of Business and Retail Management Research, 12(3).

Karadag, H., 2015. Financial management challenges in small and medium-sized enterprises: A strategic management approach. EMAJ: Emerging Markets Journal, 5(1), pp.26-40.

Nandonde, F.A. \& Kuada, J. 2016. Modern food retailing buying behaviour in Africa: the case of Tanzania. British Food Journal, 118(5):1163-1178.

Ntema, L. \& Marais, L. 2010. Trade is in our blood: Reflections on trends and conflicts in township trade. CDS Research Report, LED and SMME Development, (1):60.

Otoo, M., Ibro, G., Fulton, J. \& Lowenberg-Deboer, J. 2012. Micro-entrepreneurship in Niger: factors affecting the success of women street food vendors. Journal of African Business, 13(1):16-28.

Porter, M.E. 2008. 'The five competitive forces that shape strategy'. Harvard Business Review, 86(1):78-94.

Qamruzzaman, M. and Jianguo, W., 2019. SME financing innovation and SME development in Bangladesh: An application of ARDL. Journal of Small Business \& Entrepreneurship, 31(6), pp.521-545.

Salimov, S.Y. 2018. The development of small business and private entrepreneurship. International Journal of Economics and Management Sciences, 7(4):4-5.

Sekaran, U. \& Bougie, R. 2016. Research methods for business: a skill building approach. 5th ed. New York: Hermitage

Singer, S., Amoros, J.E., \& Moska, D. 2014. Global monitor report (2014) Global Report. 
Spremo, Т. and Mićić, J., 2015. Small enterprises: Key source of employment and economic growth. ЗБОРНИК РАДОВА ЕКОНОМСКОГ ФАКУЛТЕТА У ИСТОЧНОМ САРАЈЕВУ, 4(11), pp.63-73.

Strydom, J. 2015. David against Goliath: predicting the survival of formal small businesses in Soweto. International Business and Economics Research Journal, 14(3):463-476.

Strickland, A.J., Piteref, M., Gamble, J. and Thompson, A.A., 2016. Strategic management. Creating a competitive advantage. Trans. from English. Moscow, Williams [in Russian].

Wang, Y. 2016. What are the biggest obstacles to growth of SMEs in developing countries? An empirical evidence from an enterprise survey. Borsa Istanbul Review, 16(3):167-176 